\title{
Márta Radó*
}

Corvinus University of Budapest

\section{THE EFFECT OF RETIREMENT ON PERCEIVED WELL-BEING IN HUNGARY ${ }^{1}$}

\begin{abstract}
The effect of retirement on perceived well-being is examined by using three waves of the Hungarian GGS data. The marginal log-linear model, which is a useful, state-of-the art methodological tool for categorical multivariate analysis, is applied to the problem. This paper ascertains that retirement has a significantly negative effect on an individual's perceived well-being, although after three years of retirement the feeling of well-being starts to increase again. The significant decrease after retirement can be explained by the health and age of the individual, since those in living poor health and retiring at a younger age tend to have lower subjective well-being. Thus retirement and subjective well-being are conditionally independent given health and age. This paper also reveals that the perceived well-being of those who have retired between the first and the second wave is a Markov chain. This means that the perceived well-being measured in the third and the first waves are conditionally independent given the well-being measured in the second wave. The results support the idea that retirement causes a temporary reduction in well-being.
\end{abstract}

Keywords: retirement, marginal log-linear models, perceived well-being

\section{INTRODUCTION}

We are witnessing apace ageing of the population in developed countries. Aging means there are fewer people to pay taxes, while the number of elderly who need to rely on pension systems is increasing. These demographical trends not only endanger pension systems, but also raise questions as to what kind of standards of living are waiting for the growing number of elderly. Understanding what retirement means in the life course of individuals has become a highly policy-relevant field.

The focus of this paper is the impact of retirement on perceived living conditions. 'Perceived living condition' is a subjective indicator which directs attention from external measurement to an individual's self-evaluation. The subjective indexes have become widely

* Corresponding author: Márta Radó, Corvinus University of Budapest, Institute of Sociology and Social Policy, Közraktár utca 4-6, H-1093 Budapest, Hungary; e-mail: marti.rado@gmail.com.

1 I hereby state that the present study presents the results of an original research solely done by the author. This paper was written as part of a Hungarian Scientific Research Fund project (OTKA K104707). 
used in policy analysis, since it is recognized that policies should aim to provide a life which is considered to be a 'good life' for the stakeholder.

A state-of-the-art methodological tool, the marginal log-linear model, is applied to this problem. This method can be used for categorical multivariate analysis. This paper briefly introduces how this method can be employed in conducting longitudinal data analysis. This secondary analysis is based on data collected in 2001, 2004 and 2008 by the Hungarian Statistical Institute in its Turning Points of the Life Course research.

This paper shows that retirement has a negative effect on the perception of well-being indeed. However, this negative relationship can be explained by the health and age of the retirees. In other words, this paper draws attention to the fact that the form and condition of retirement matters, as it is not simply an exit from the labor market.

\section{THEORIES AND PREVIOUS RESEARCH}

\section{OBJECTIVE AND SUBJECTIVE INDICATORS}

In the 1970s a heated debate arose about the relationship between subjective and objective well-being. This time it was realized that a relationship between subjective and objective measures exists, although these relationships are often weak. Cummins (2000) also points out that the correlation within subjective indicators and an objective indicators is stronger than between subjective and objective indicators.

There have been several efforts to explain the difference between objective and subjective indicators. Diener et al. (1997) stress that discrepancy between subjective and objective indicators can be attributed to the fact that individuals compare themselves to a reference group, and the group of relevant others varies among life conditions and statuses. This theory explains why people living under favorable conditions usually underestimate their positions. Cummins (2000) argues that the normal state of an individual is happiness, since it is important in dealing with daily life. He argues that people tend to distort reality using misperceptions in order to maintain happiness. Thus people tend to overestimate their lives and accomplishments. Finally, Michalos (1985) argues that subjective indicators depend on the will and evaluation of the individual, the person's experience, and on the possessions of others relevant to them.

There has been a long debate whether objective or subjective indicators should be used for policy analysis. Mainly we can distinguish between two kinds of approaches: the Scandinavian welfare approach and the American quality-of-life approach. The first considers welfare as an "individuals command over, under given determinants mobilizable resources, with whose help he/she can control and consciously direct his/her living conditions" (Erikson 1974: 275). Resources are defined as money, property, knowledge, mental and physical energy, social relations, security and so on. (Noll 2004) So this approach focuses on objective living standard indicators. In contrast, the American quality-of-life approach bases welfare measurement on subjective indicators. Thomas argues that subjective indicators are important since "if men define situations as real, they are real in their consequences" (Thomas 1928: 571-572). 
This approach emphasizes that the individual is the best expert to evaluate his or her quality of life. Scandinavian researchers have criticized this subjective quality of life approach in the following way: "with an approach based on people's own assessment of their degree of satisfaction is that it is partly determined by their level of aspiration" (Erikson 1993: 77).

Schultz (2000) distinguishes four types of variables (see Tab. 1) along a continuum ranging from "more objective" to "more subjective". These sets of variables are defined as Social Structure (Group A), Resources and Behavior (Group B), Evaluation of Living Conditions (Group C), and Subjective Quality of Life (Group D). Groups C and D are considered to contain variables in which evaluation and cognitions are clearly predominant, so we can call them subjective variables. He points out that there are different approaches to how overall subjective quality of life (Group D) should be explained according to use of variables from Group A, B or C as an independent variable.

Table 1. Schultz typology about social indicators

\begin{tabular}{|l|l|l|l|}
\hline \multicolumn{1}{|c|}{ Group A } & \multicolumn{1}{c|}{ Group B } & \multicolumn{1}{c|}{ Group C } & \multicolumn{1}{c|}{ Group D } \\
\hline Social structure & $\begin{array}{l}\text { Resources and behav- } \\
\text { ior (living conditions) }\end{array}$ & $\begin{array}{l}\text { Evaluation of living } \\
\text { conditions }\end{array}$ & Quality of life \\
\hline $\begin{array}{l}\text { Socio-demographic } \\
\text { (e.g. sex, age) }\end{array}$ & $\begin{array}{l}\text { Standard of living (e.g. } \\
\text { housing, health) }\end{array}$ & $\begin{array}{l}\text { Domain Satisfaction, } \\
\text { importance of life do- } \\
\text { mains, perceived need } \\
\text { and fulfilment }\end{array}$ & $\begin{array}{l}\text { Well-being, satisfac- } \\
\text { tion, happiness }\end{array}$ \\
\hline
\end{tabular}

Hegedüs (2002) distinguishes three kinds of subjective indicators. The first implies a personal evaluation in an indirect way. For example, a variable which measures one's preferred way for the government to spend their taxes belongs to this category. The second type of subjective indicator measures the subjective well-being evaluation in a direct way. She argues that the perception of an individual's income belongs to this category. The third type goes beyond the simple description of subjective well-being and also incorporates a qualification process. The typical question for this type is satisfaction of life or happiness (Hegedüs 2002: 37).

The key variable of this paper is the perception of living conditions, which falls under the second category of Hegedüs's typology and Group C of Schultz's typology. Both of these typologies emphasize that the perception of living standards is clearly a subjective variable. As well, Kapitány and Spéder (2006) point out that this variable measures subjective well-being since it does not only reflect objective living conditions, but also depends on the reference group of the individual.

\section{THE EFFECT OF RETIREMENT ON OBJECTIVE LIVING CONDITIONS}

The focus of this paper is the effect of retirement on the perception of living conditions, which is considered to be a subjective indicator. However, as in the previous chapter it has 
been shown that objective indicators also play an important role. Thus this chapter will introduce the objective changes around this life event.

Molnár (2001) points out that three main crucial losses can be attributed to the aging process: change in economic status, decline in health, and loss of social connections. The first loss, changes in economic activity, also implies a decline in income. The third loss, that of social connections, reflects changes in family life, namely, children leaving home and the death of a partner. Sometimes elderly parents move in with their child's family. However, Molnár argues that this step usually happens due to economic constraints and not due to preferences of living with children, as this kind of cohabitation is more prevalent in poorer families. Molnar points out that these three losses are the worst for newly retired people since they experience a decrease in income and the need to adapt to the new day-to-day living conditions. Molnar's analysis is based on the first wave of the Turning Points of the Life Course research. She also notes that a longitudinal dataset would reveal more information about the living standards of the elderly.

Besides income and household composition, another important dimension of living conditions is housing. Dóra (2001) points out that the elderly usually live in a bigger house relative to their income since mobility is quite low in Hungary. Therefore their main problem is high maintenance costs. Moreover Molnár (2004) shows that the facilities of the elderly mostly differ from the younger generation in terms of modernity. For example, there is a sizeable difference between people over and under sixty in terms of owning a microwave.

Monostori (2008) has analyzed the first and the second waves of the Turning Points of the Life Course research, so she already had longitudinal data. She has shown that between 2001 and $200419.3 \%$ of people over 40 experienced a decline in their income. In the same period $30 \%$ of the retired and $50.2 \%$ of the disability-retired people had such an experience. She also points out that there is a correlation between retirement and decline in health. $9 \%$ of those over 50 said in 2001 that they had no permanent health problem, but did in 2004. In comparison, $23.9 \%$ of retired people experienced such a decline in their health. She stresses the point that declining health is not only a consequence of retirement, but also a reason for taking it. Health can be improved due to retirement as the individual is relieved of workrelated stress. Health can decline right after retirement, however, as the individual loses social connections, income and their role in society. She also stresses the point that the timing and form of retirement is very important in terms of well-being after retirement.

There is a growing number of international studies dealing with the question of how objective well-being changes after retirement. For example, in the US there is a comprehensive study (Older Americans 2000: Key Indicators of Well-Being) published by the Federal Interagency Forum on Aging Related Statistics.

\section{THE EFFECT OF RETIREMENT ON SUBJECTIVE LIVING CONDITIONS}

Several studies have observed the effect of retirement on subjective living conditions. In Hungary Molnár (2004) has shown how the perception of living conditions changes due to aging and retirement. She has shown that 60-75-year-olds have the same subjective wellbeing as younger people. However according to a retrospective question, those aged 60-75 
experienced a greater decline in their life conditions than younger people did. $43 \%$ of the 60-75-year-old population said that they had experienced a decline in their life condition compared to $33 \%$ of the entire population. Molnár argues that this difference can be caused by the three crucial losses (more about that in 2.2). She also has shown that the most unsatisfied people are those who are recently retired, since these people suddenly face a loss of income. As it was pointed out in the previous chapter, she uses a cross-sectional study to observe this very issue.

Monostori (2008) uses a longitudinal study, although her key variable is satisfaction with one's entire life and not the perception of living conditions. She has found that subjective well-being can be explained mostly "by the health, the equivalent household income and whether somebody has experienced unemployment during his or her life course" (Monostori 2008: 109). As well, this research focuses solely on subjective well-being measured only after retirement. This paper argues that subjective elements before and after retirement need to be compared in order to see the effects of retirement.

There is a huge body of international literature on how subjective well-being changes due to retirement. However, these research projects mostly focus on satisfaction with life and only a handful of research projects deal with perceived living conditions. For example, Barrett and Kecmanovic (2012) observe perceived living condition changes. They have found that the age of retirement matters considerably in terms of effects of retirement. People between 45-54 at the time of retirement tend to experience a decline, those between 55-74 show no significant difference, and older people even experience improvement. However, Barrett and Kecmanovic observe the perception of living conditions before retirement by the help of retrospective questions. The next chapter argues why longitudinal analysis would be appropriate to observe this topic.

\section{DATA}

This research is based on the dataset of the Turning Points of Life Course program (Hungarian GGS), longitudinal research done by the Hungarian Central Statistical Office. The first wave was conducted in 2001, the second in 2004 and the third in 2008. 10,641 people were surveyed in this research, dealing with only those over 45 , since retired people should not be compared with much younger people. 3,865 people in the sample were older than 45 in 2001.

Single observation would be only sufficient for this research question if people were able to recall their past perfectly. We can assume this about certain questions (e.g. "When did you get married?"), but subjective elements cannot be observed by retrospective questions. Retrospective questions can be asked only if we are interested in what the individuals recently think about their previous feelings, but these answers always imply the individual's recent experience and feelings (Spéder 2003:14). Also, repeated cross-sectional studies would not be able to solve this puzzle sufficiently, since we are not only interested in overall trends which can be identified by comparing the two cross-sections ("net change"), but in the transitions at the individual level ("gross change"), which can be observed only by a longitudinal dataset 
(Bergsma, Croon and Hagernaars 2009). In other words, the aim of the study is not only to compare the subjective element of certain groups in different time periods, but also to trace who has changed and in which direction in terms of their perceived well-being in a given period. This means that neither a retrospective nor a repeated cross-section study would suffice for this research question; it can be observed only with longitudinal data.

\section{METHODOLOGY}

In this paper marginal log-linear models are applied which enable us to conduct multivariate analysis with categorical data. Thus it is possible not only to make two-dimensional analyses, but to take into account certain confounding variables as well. Categorical data analysis is very important because most of the sociological data are not continuous. Statistically speaking, it is not appropriate to apply categorical data to any method which was developed for continuous data. As well, most of these methods almost automatically assume multivariate normality, which is even rarer in social science. Moreover, the advantage of categorical data analysis is that it allows for richer structure than analysis which relies on assumption of multivariate normality. For example, if three variables had a joint normal distribution, the independences $\mathrm{A} \perp \mathrm{B}$ and

$\mathrm{A} \perp \mathrm{C}$ also imply the independence $\mathrm{B} \perp \mathrm{C}$. This means that these variables' joint distribution can be given by $\left(\begin{array}{l}A \\ B\end{array}\right),\left(\begin{array}{l}A \\ C\end{array}\right)$ and $\left(\begin{array}{l}B \\ C\end{array}\right)$ distributions. In contrast, in case of discrete variables $\mathrm{AB}, \mathrm{BC}$ and $\mathrm{AC}$ marginal do not define the joint distribution of these three variables (Bergsma and Rudas 2002). Finally, Bergsma et al. (2009) argue that marginal log-linear models are also useful for analyzing longitudinal data since it enables one to conduct an analysis in which observations are not independent from each other (the same people are asked in every wave). This paper only briefly introduces the statistical background of the marginal log-linear models (more about this topic can be found in Rudas and Bergsma (2004); Németh (2009); Rudas, Bergsma and Németh (2006); Rudas, Bergsma and Nemeth (2010) and Bergsma, Croon and Hagenaars (2009)) This introduction is mostly based on the work of Németh (2009), which is the source unless otherwise indicated.

The general log-linear representation of a two-dimensional contingency table is an additive parameterization of logarithm of cell frequencies

$$
\ln \mu_{i j}=\lambda_{0}^{A B}+\lambda_{i}^{A}+\lambda_{j}^{B}+\lambda_{i j}^{A B}
$$

where $\lambda_{0}^{A B}$ is the overall effect, $\lambda_{i}^{A}$ is the effect of category $i$ of $A, \lambda_{j}^{B}$ is the effect of category $j$ of $B$, and $\lambda_{i j}^{A B}$ is the interaction effect of category $i$ of $A$ and category $j$ of $B$. In the same way more dimensional parameters can be included in the model. In case of general log-linear parameters $\left(\lambda_{L}^{V}\right)$ the upper index of the parameter $(V)$ shows all the observed variables, whereas the downer index $(L)$ includes a subset of the complete set of variables. $\lambda_{L}^{V}$ parameter represents the effect of the variables which are in the downer index $(L)$ controlled for the variables 
included in the upper index, but not included in the downer index $(V-L)$. For example, let variable $A$ measure the age as a binary variable (it can take value of 0 if the respondent is young and value of 1 if the respondent is old). Let $E$ represent the level of education (it can take value of 0 if the respondent is uneducated and value of 1 if the respondent is educated) and I represent the income (it can take value of 0 if the respondent has low-income and value of 1 if the respondent has high-income). The parameter $\lambda_{* 11}^{A E I}$ shows the effect of education on wealth under control of age. It is important to note that the concept of effect in this method does not imply causal relationship.

General log-linear parameters always include the complete set of variables in the analysis. In certain cases we do not want to use all the observed variables in the analysis. For example, in case of a longitudinal analysis we may not want to explain a dependent variable which was measured in the second wave by a variable from the third wave. Or to use the previous example, we are only interested in the effect of education on income without controlling for age. In this case we use marginal log-linear parameters $\left(\lambda_{L}^{M}\right)$, in which the upper index $(M)$ is the subset of the complete set of variables $(V)$. So in contrast to the general log-linear models, marginal log-linear models make it possible to control for only certain variables $(M-L)$ and not for all variables $(V-L)$.

Marginal log-linear models assume that certain effects are not that important and set those parameters equal to 0 , which means that we omit them from the model. Thus we gain a model which highlights the important associations. Three kinds of model restriction will be observed in this paper.

The first one tests (2) conditional independence. $A$ and $B$ are conditionally independent from each other given $C$ can be stated by the following formula:

$$
\lambda_{A B C}^{A B C}=\lambda_{A B}^{A B C}=0
$$

The second kind of restriction which is used in this paper is (3) testing whether two parameters are equal. For example, Németh (2009) tests whether the association of two variables remains constant over time. She has shown that association between belonging to a certain cohort $(C)$ and subjective well-being $(S)$ at different points in time is time invariant:

$$
\lambda_{C S_{1}}^{C S_{1}}=\lambda_{C S_{2}}^{C S_{2}}
$$

By subtracting $\lambda_{C S_{2}}^{C S_{2}}$ it can be converted to the following equation:

$$
\lambda_{C S_{1}}^{C S_{1}}-\lambda_{C S_{2}}^{C S_{2}}=0
$$

In this case the difference of two variables is set to 0 .

And finally a marginal log-linear model is used to (5) test $1^{\text {st }}$-order Markov chains. For this setup we need to have longitudinal data and ask the same individuals several times about the same variable. A $K$-th order Markov chain means that the conditional distribution of the 
variables measured at time point $t$ depends only on the positions at the $k$ preceding time points. For example, Németh (2009) observes the pattern of change in satisfaction subjective wellbeing $(S)$. She tested whether subjective well-being measured in three waves of the Hungarian Household Panel make a $1^{\text {st }}$-order Markov chain. This means that subjective well-being measured in the third wave $\left(S_{3}\right)$ is conditionally independent from satisfaction measured in the first $\left(S_{1}\right)$ wave given satisfaction measured in the second wave $\left(S_{2}\right)$.

$$
\lambda_{S_{1} S_{2} S_{3}}^{S_{1} S_{2} S_{3}}=\lambda_{S_{1} S_{2}}^{S_{1} S_{2} S_{3}}=0
$$

The appropriateness of fit of each model restriction can be tested by a likelihood ratio test $\left(G^{2}\right)$. If the model is true than these test statistics have an asymptotic Chi-square distribution. The degree of freedom in this case is equal to the number of parameters which were set to 0 . If the P-value is less than or equal to 0.05 then the postulated model is rejected. As well, we can test whether a model fits better than an alternative model. Let us assume that we have two nested models: $M_{1}$, with $d f_{1}$ degrees of freedom and an alternative model $M_{2}$, with $d f_{2}$ degrees of freedom which contains model $M_{1}$ as a special case $\left(M_{1} \subset M_{2}\right)$. The conditional test statistic is then defined as

$$
G^{2}\left(M_{1} \mid M_{2}\right)=G^{2}\left(M_{1}\right)-G^{2}\left(M_{2}\right)
$$

and has an asymptotic chi-square distribution with $d f=d f_{1}-d f_{2}$ if $M_{1}$ is true (Bergsma, Croon and Hagernaars 2009). If the two models are not nested then we use the BIC statistics which is defined as

$$
\mathrm{BIC}=2\left[G^{2}\left(M_{2}\right)-G^{2}\left(M_{1}\right)\right]-\log n \cdot\left(d f_{2}-d f_{1}\right)
$$

where $n$ is a quantity describing the amount of information in the sample (for independent data it is the number of observations). The smaller the BIC statistic, the better the fit of the model (Kuha 2010).

This paper shows examples for these three restrictions. The Markov-chain models and models which contain restriction about conditional independence are directed acyclic graphs (DAG). Directed acyclic graphs are those whose vertices are connected with arrows (directed edges) and no directed cycles are present. In these graphs a lack of an arrow between two variables means conditional independence given the parents of either one. If we have an arrow from $A$ to $B$ then we refer to $A$ as the parent of $B$. One type of DAG is the path model. Path models assume that all hierarchical marginal log-linear parameters not associated with an arrow are zero (Rudas, Bergsma and Németh 2006), so categorical path models can be obtained by setting higher than first-order effects to zero. This is a very interpretable graph since arrows represent effects in these graphs. (For more on graphical models see Németh's (2009) $\mathrm{PhD}$ dissertation.)

Finally, the analysis presented in this paper was conducted using the $\mathrm{cmm}$ package (Bergsma 1997; Bergsma, Croon and Hagenaars 2009) of R software (Németh 2010). 


\section{VARIABLES}

The dependent variable in this paper is the perceived living condition of the individual. The perceived well-being, measured in different $(t)$ waves, is treated as a different variable $\left(W_{t}\right)$. So $W_{1}$ is the measured wellbeing in the first wave, $W_{2}$ is the measured wellbeing in the second wave and $W_{3}$ is the measured wellbeing in the third wave. The following question was asked in each wave: "How would you rate your present living conditions?" (Hungarian Central Statistical Office 2001: 130, Hungarian Central Statistical Office 2004: 33, Hungarian Central Statistical Office 2008: 47). It was measured on an 11-point scale in which 10 represents the optimal living conditions and 0 the worst. Those responding $0-3$ were coded as someone with low perceived well-being, those within 4-7 were considered to have average well-being, and those falling in the range of 7-10 were coded as having high perceived well-being.

This paper compares those who retired between 2001 and 2004 with those who did not retire in this given period. The event of retirement was known from the dataset measured in 2004. Since this paper focuses on the effect of retirement, those who retired before 2001 were not involved in the analysis. Overall, there were 478 people in the sample who retired between 2001 and 2004.

Health is also involved in the analysis since it can have a crucial effect on the relationship between retirement and perceived well-being. This was also measured in 2004 by the following question: "indicate how satisfied you are with the state of your health. 0 means that you are not at all satisfied and 10 that you are fully satisfied." (Hungarian Central Statistical Office 2004: 39). Subjective health status was used since medical opinion was not available. Nevertheless, it has been shown that subjective well-being is not only an easily assessable measurement, but also it is a better predictor of mortality than doctors' opinions. (Idle and Benyamini 1997). In this paper subjective health was recoded to a binary variable. Those people who rated their health between 0 and 4 were coded to the group with poor health status and those who rated their health as 5 or more were considered as healthy.

Finally, age category is also used as a control variable. Those people between 45 and 53 in 2001 were considered as young, and those over 54 were considered as old. This age category is strongly connected to the age of retirement. Therefore, belonging to the young age group also implies early retirement.

\section{RESULTS}

\section{THE RELATIONSHIP BETWEEN RETIREMENT AND SUBJECTIVE WELL-BEING IN EACH WAVE}

First of all, the relationship between perceived well-being and retirement was tested in each wave (Table 2 presents the testing of independence of retirement and well-being). In loglinear models the independence in a $2 \times 3$ contingency table can be tested by the observation of the model in which the interactional effect is equal to zero. If the $\mathrm{P}$ value is higher than 0.05 then we accept that the two variables are independent from each other. 
The results show that there is a significant association between retirement and perceived well-being in each wave. So this means that those who retired between 2001 and 2004 experience significantly different levels of well-being before and after retirement (in the short term and in the longer term as well) than those who had not retired. However, it is important to note that because of the relatively large sample (3,865 people) only small differences can turn out to be significant.

Table 2. Testing independence of retirement and subjective well-being in each wave

\begin{tabular}{|l|c|c|c|}
\cline { 2 - 4 } \multicolumn{1}{c|}{} & $\boldsymbol{G}^{\mathbf{2}}$ & $\boldsymbol{d f}$ & $\boldsymbol{P}$-value \\
\hline $\begin{array}{l}\text { Retirement between } 1^{\text {st }} \text { and } 2^{\text {nd }} \text { waves or not } \times \text { Subjective } \\
\text { well-being in the } 1^{\text {st }} \text { wave }\end{array}$ & 6.86 & 2 & 0.03 \\
\hline $\begin{array}{l}\text { Retirement between } 1^{\text {st }} \text { and } 2^{\text {nd }} \text { waves or not } \times \text { Subjective } \\
\text { well-being in the } 2^{\text {nd }} \text { wave }\end{array}$ & 8.02 & 2 & 0.02 \\
\hline $\begin{array}{l}\text { Retirement between } 1^{\text {st }} \text { and } 2^{\text {nd }} \text { waves or not } \times \text { Subjective } \\
\text { well-being in the } 3^{\text {rd }} \text { wave }\end{array}$ & 10.36 & 2 & 0.01 \\
\hline
\end{tabular}

Figure 1 shows how perceived well-being changed over the three waves (2001, 2004 and 2008) according to whether someone retired between the first and the second waves (between 2001 and 2004). In 2001 we can see that those who retired in the following three years (between 2001 and 2004) had expressed less polar levels of perceived well-being than those who did not retire. In 2004 those people who had just retired in the previous three years had lower perceived well-being than those who did not retire. This association did not fade away four years later. In 2008 those people who had retired between 2001 and 2004 still had lower perceived well-being than those who did not retire in that given period.

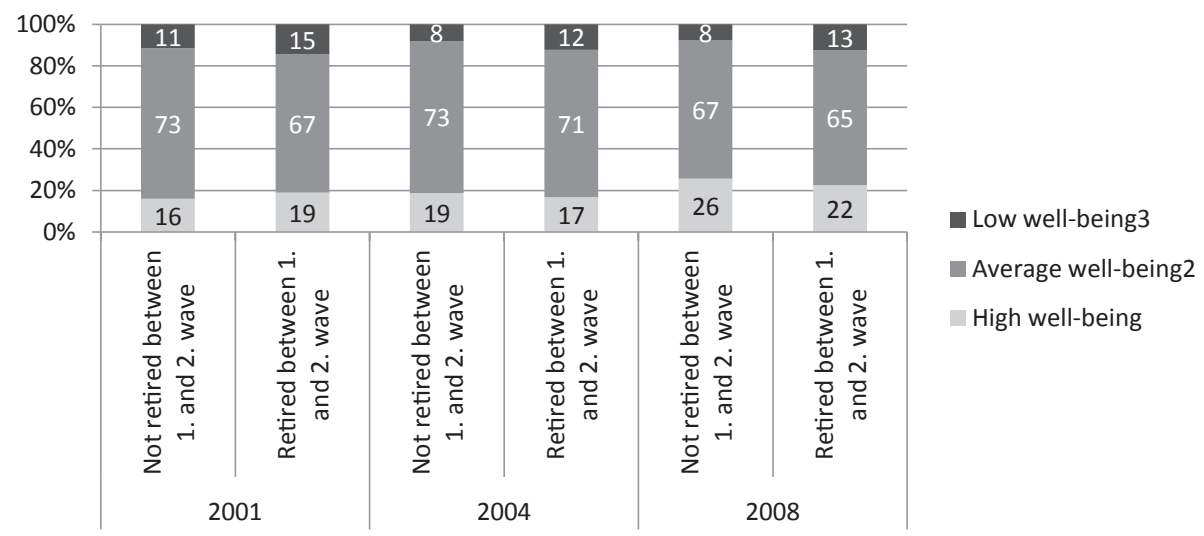

Figure 1. Relationship between perceived well-being and retirement in 2001, 2003 and 2008 (\%) 
Those who retired between 2001 and 2004 experienced a decrease in well-being right after retirement, although at least four years after retirement their perceived well-being started to increase. It is important to compare the retired people's change in well-being with that of the non-retired people in order to rule out the effects of aging. In contrast to retired people, those who had not retired between 2001 and 2004 on average experienced an increase in well-being in each wave. This means that perceived well-being actually improves with ageing. Since aging has a positive effect on perception of well-being, even a slight change in well-being right after retirement can be important. This question is dealt with in the following chapter.

\section{CHANGES IN PERCEIVED WELL-BEING AROUND RETIREMENT}

In the previous chapter saw that those who retired between 2001 and 2004 and those who did not retire $(R)$ had significantly different perceived well-being $(W)$ in both 2001 and 2004. In this chapter a change between 2001 and 2004 is observed among those who retired in this period and those who did not retire in this period. A model is tested which assumes that whether someone retiring between 2001 and 2004 or not has a constant effect on perceived well-being in 2001 and 2004. This is equivalent with the following log-linear statement:

$$
\lambda_{W_{1} R}^{W_{1} R}=\lambda_{R W_{2}}^{R W_{2}}
$$

This can be transformed for the following equilibrium by subtracting $\lambda_{R W_{2}}^{R W_{2}}$ :

$$
\lambda_{W_{1} R}^{W_{1} R}-\lambda_{R W_{2}}^{R W_{2}}=0
$$

The model with this restriction, however, does not fit well $\left(G^{2}=9.33, d f=2, P\right.$-value $\left.=0.01\right)$ so we need to reject this statement. The relationship between retirement and subjective wellbeing is not constant in the two waves. This means that well-being changes between 2001 and 2004 significantly differently between retired and non-retired people. So retirement means a temporary reduction in terms of perceived well-being.

\section{PERCEIVED WELL-BEING AS A $1^{\text {ST }}$-ORDER MARKOV CHAIN}

This paper tests whether the perceived well-being of those who retired between the first (2001) and second (2004) waves makes a $1^{\text {st }}$-order Markov chain in the observed three waves $(2001,2004,2008)$. This would mean that the perception of well-being measured in the third wave $\left(W_{3}\right)$ is conditionally independent from the well-being measured in the first wave $\left(W_{1}\right)$ given the well-being measured in the second wave $\left(W_{2}\right)$. The $1^{\text {st }}$-order Markov chain states the following conditional independence:

$$
W_{3} \perp W_{1} \mid W_{2}
$$


This means that the subjective well-being measured at least four years after retirement only depends on the subjective well-being measured a few years after retirement, and if we know how the individual was right after retirement than the pre-retirement period has no additional influence on perceived well-being (see Fig. 2).

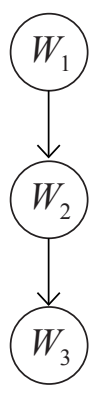

Figure 2. Perceived well-being in the three waves as a $1^{\text {st }}$-order Markov chain

The model in Figure 2 fits well $\left(G^{2}=20.19, d f=12\right.$ and $P$-value $\left.=0.06\right)$. So perceived well-being develops smoothly after retirement.

\section{CONFOUNDING VARIABLES IN THE RELATIONSHIP BETWEEN RETIREMENT AND WELL-BEING}

Finally, a model was built in order to gain a more precise picture about the relationship between well-being and retirement (See more in the variable description chapter). The following variables are included in this model:

- age group (A),

- whether the individual retired between 2001 and 2004 (R),

- health status after retirement $(\mathrm{H})$,

- well-being in 2004 (W).

In order to obtain the best-fitting model a saturated model was assumed and arrows were left out one by one. In the first stage six arrows can be omitted. Omitting an arrow represents conditional independent statements (See more in the methodological part).

In Table 3 we can see that Model 1 and Model 2 fit well since $P$-values are higher than 0.05 in these models. This table also shows that Model 1 fits better than Model 2 since the former has a lower BIC value (see more about the goodness of fit in the methodology chapter). Model 7 is also tested, which contains the restriction of Model 1 and Model 2. So it omits both AW and RW arrows from the saturated model. 
Table 3. Choosing the best fitting model by leaving out one arrow

\begin{tabular}{|l|c|c|c|c|c|}
\hline Model no. & Omitted arrow & $\boldsymbol{G}^{\mathbf{2}}$ & $\boldsymbol{d} \boldsymbol{f}$ & $\boldsymbol{P}$-value & BIC \\
\hline Model 1 & RW & 4.56 & 8 & 0.80 & -57.34 \\
\hline Model 2 & AW & 10.16 & 8 & 0.25 & -51.75 \\
\hline Model 3 & HW & 185.51 & 8 & 0.00 & 123.61 \\
\hline Model 4 & RH & 101.78 & 6 & 0.00 & 55.36 \\
\hline Model 5 & AR & 448.37 & 6 & 0.00 & 401.94 \\
\hline Model 6 & AH & 34.48 & 6 & 0.00 & -11.94 \\
\hline
\end{tabular}

We can see in Table 4 that Model 7 also fits well; however, it has significantly lower goodness of fit than Model 1. Finally, it was tested whether Model 1 could be a path model. This would mean that only first-ordered effects would need to be retained and higher effects omitted. This model does not fit well $\left(G^{2}=58.30, d f=10\right.$ and the $P$-value $\left.=0.00\right)$.

Table 4. Choosing the best fitting model by testing a nested model

\begin{tabular}{|c|c|c|c|c|c|c|c|c|}
\hline \multicolumn{3}{|c|}{ Model 1 } & \multicolumn{3}{c|}{ Model 7 } & \multicolumn{3}{c|}{ Model 7 - Model 1 } \\
\hline $\boldsymbol{G}^{\mathbf{2}}$ & $\boldsymbol{d} \boldsymbol{f}$ & $\boldsymbol{P}$-value & $\boldsymbol{G}^{\mathbf{2}}$ & $\boldsymbol{d} \boldsymbol{f}$ & $\boldsymbol{P}$-value & $\boldsymbol{G}^{\mathbf{2}}$ & $\boldsymbol{d} \boldsymbol{f}$ & $\boldsymbol{P}$-value \\
\hline 4.56 & 8 & 0.80 & 15.87 & 12 & 0.20 & 11.31 & 4 & 0.02329 \\
\hline
\end{tabular}

To sum up, Model 1 is retained as the best-fitting model. This model says that well-being in 2004 is conditionally independent of someone retired between 2001 and 2004 given their health in 2004 and the age category.

$$
\mathrm{R} \perp \mathrm{W} \mid \mathrm{HA}
$$

This model's graphical figure is shown in Figure 3.

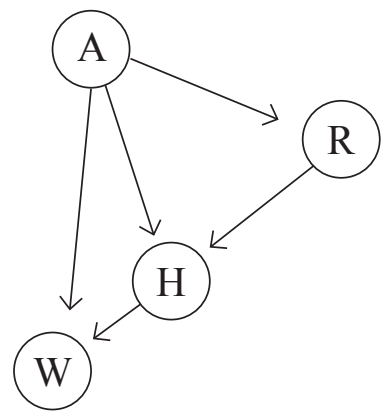

Figure 3. Confounding variables in the relationship between retirement and well-being 
This means that retirement has a negative effect on perceived well-being, but this can be explained by the health and age of the individual. Age means here how old the individual was at the time of retirement. People who retire at a younger age tend to be non-voluntary retirees, which has a crucial effect on perceived well-being. This result highlights the importance of the way of retirement.

\section{CONCLUSIONS}

This paper observes how one's perceived living condition changes with retirement. Thus the key variable is a subjective indicator. This concept goes beyond observing pure economic conditions. Behind the usage of this indicator lies the assumption that the stakeholder is the best expert to evaluate his or her living conditions. Recently this approach has been widely adopted by policy-makers.

The international and Hungarian research projects on this topic usually rely on crosssectional studies. In this paper it has been argued that longitudinal studies are necessary in order to accurately perceive the effects of retirement. Consequently, this study shows a secondary analysis of the Turning Points of the Life Course research, which is a longitudinal dataset collected by the Hungarian Statistical Institute in 2001, 2004 and 2008. The applied methodology is marginal log-linear models, which can be used for categorical multivariate analysis.

This paper shows that retirement indeed has a negative effect on the perception of wellbeing. In the analysis people who retired between 2001 and 2004 are compared to those who were older then 45 , but did not retire in that given period. Retired people have significantly lower perceived living conditions than the control group in both before (2001) and after (2004 and 2008) retirement. This paper also deals with the changes in perceived living conditions. It shows that there is a significant difference between retirees' and non-retirees' perceptions on living condition changes between 2001 and 2004. In this given period retired people's well-being does not change, but the control group's well-being increases, which indicates a significant difference between the two groups. However, the significant difference between retirees and non-retirees can be explained by health and age. This supports the idea that it is not retirement itself that matters, but the form of retirement.

\section{REFERENCES}

Barrett, Garry F. and Milica Kecmanovic. 2012. Changes in subjective well-being with retirement: assessing savings adequacy, McMaster University in its series Social and Economic Dimensions of an Aging Population Research Papers with number 296, http://socserv. mcmaster.ca/sedap/p/sedap296.pdf [10.10.2013].

Bergsma, Wicher P. 1997. Marginal models for categorical data, Tilburg, The Netherlands: Tilburg University Press, http://stats.lse.ac.uk/bergsma/pdf/bergsma_phdthesis. pdf [10.10.2013]. 
Bergsma, Wicher P., Marcel A. Croon and Jacques A. Hagenaars. 2009. Marginal models for dependent, clustered and longitudinal categorical data, New York: Springer.

Cummins, Robert A. 2000. Objective and subjective quality of life: an interactive model, "Social Indicator Research" 40: 189-216.

Diener, Ed, Eunkook Suh and Shieghiro Oishi. 1997. Recent finding on subjective well-being, "Indian Journal of Clinical Psychology" 24(1), March: 25-41.

Dóra Ilona. 2001. Lakásváltozások és családi életciklusok, "Statisztikai Szemle": 79, 12: 984-1000.

Erikson, Robert. 1993. Descriptions of Inequality: The Swedish Approach to Welfare Research, in: Martha Nussbaum, Amartya Sen (eds), The Quality of Life. Oxford: Clarendon Press, pp. 67-87.

Erikson, Robert. 1974. Welfare As A Planning Goal. "Acta Sociologica” 17, 3.

Hegedüs, Rita. 2002. Szubjektiv társadalmi indikátorok- szubjektiv áttekintés a téma irodalmából, in: György Lengyel (ed.), Indikátorok és elemzések, Budapest: BKÁE

Hungarian Central Statistical Office. 2001. Életünk Fordulópontjai (Társadalmi demográfiai panelfelvétel) 1. hullám, http:/www.demografia.hu/letoltes/dpa/Kerd_1hull.pdf [03.03.2014]

Hungarian Central Statistical Office. 2004. Életünk Fordulópontjai (Társadalmi demográfiai panelfelvétel) 2. hullám, http://www.demografia.hu/letoltes/dpa/Kerd_2hull.pdf [03.03.2014].

Hungarian Central Statistical Office. 2008. Életünk Fordulópontjai (Társadalmi demográfiai panelfelvétel) 3. hullám, http://www.demografia.hu/letoltes/dpa/Kerd_3hull.pdf [03.03.2014].

Idler, Ellen L. and Yael Benyamini. 1997. Self-Rated Health and Mortality: A Review of Twenty-Seven Community Studies, "Journal of Health and Social Behavior" 38, 1:21-37.

Kuha Jouni. 2004. AIC and BIC: Comparison of Assumption and Performance, "Sociological Methods \& Research" 33, 2: 188-229.

Michalos, Alex C. 1985. Multiple discrepancies theory (MDT), "Social Indicators Research" $16,347-413$.

Molnár, Edit S. 2004. Életmód és közérzet az idősödés korában, in: Tamás Kolosi, István G. Tóth, György Vukovich (eds), Társadalmi riport 2004, Budapest: TÁRKI, pp. 152-164.

Monostori, Judit. 2008. A korai nyugdíjba vonulás okok és következmények, KSH NKI, Budapest.

Németh, Renáta. 2009. Grafikus modellek társadalomtudományi alkalmazása mobilitási adatokon, ELTE Szociológia PhD program [PhD thesis].

Németh, Renáta. 2010. Log-linear models in SPSS \& Marginal log-linear and graphical models, http://nemethr.web.elte.hu/LoglinMargGraph/ [03.10.2013].

Noll, Heintz-Herbert. 2004. Social Indicators for the quality of life, Sustainable Ageing Societies: Indicators for Effective Policy-Making, Workshop, GESIS, http://www.monitoringris.org/documents/protected/noll.pdf [10.10.2013].

Schultz, Wolfgang. 2000. Explaining Quality of Life-The Controversy between Objective and Subjective Variables, EuReporting Working Paper No. 10,: http://www.plg.at/eureporting/schulz.pdf [10.10.2013]. 
Spéder, Zsolt. 2003. Módszertan és Dokumentáció, KSH, http://www.demografia.hu/letoltes/ kiadvanyok/Muhelytanulm/muhtan2.pdf [02.03.2014].

Spéder, Zsolt and Balázs Kapitány. 2002. A magyar lakosság elégedettségének meghatározó tényezői nemzetközi összehasonlitásban, Társadalmi Riport, TÁRKI, pp. 162-172.

Rudas Tamas and Wicher Bergsma. 2004. On Applications of Marginal Models to Categorical Data. "Metron" 42: 15-37.

Rudas Tamas, Wicher Bergsma and Renata Németh. 2006. Parameterization and estimation of path models for categorical data, in: Afredo Rizzi and Maurizio Vich (eds.) COMPSTAT 2006 Proceedings in Computational Statistics, Heidelberg: Physica, pp. 383-394.

Rudas, Tamas, Wicher P. Bergsma and Renata Nemeth. 2010. Marginal log-linear parameterization of conditional independence models, "Biometrika" 97, 4: 1006-1012.

Thomas William I. and Dorothy S. Thomas. 1928. The Child in America: Behavior Problems and Programs. New York: Alfred A. Knopf.

\section{ACKNOWLEDGEMENT}

I would like to express my gratitude to Renáta Németh, who helped my work as my MsC thesis supervisor. Also I am grateful to Tamás Rudas for his useful comments on this study.

\section{WPŁYW EMERYTURY NA SUBIEKTYWNIE ODCZUWANE SAMOPOCZUCIE NA WĘGRZECH}

Artykuł przedstawia badania wpływu emerytury na subiektywnie odczuwane samopoczucie oparte na trzech falach danych $z$ węgierskiego urzędu statystycznego. Problem został zanalizowany za pomocą marginalnego modelu log-liniowego, który jest użytecznym narzędziem do analizy wieloczynnikowej. Z analizy wynika, że przejście na emeryturę ma negatywny wpływ na subiektywnie odczuwane samopoczucie jednostki, chociaż po trzech latach od momentu przejścia poziom samopoczucia zaczyna wzrastać. Jego znaczący spadek tuż po przejściu na emeryturę można wytłumaczyć zdrowiem i wiekiem jednostki, bowiem osoby z problemami zdrowotnymi i przechodzące na emeryturę w młodszym wieku zazwyczaj charakteryzują się gorszym samopoczuciem. Stąd emerytura i samopoczucie są od siebie niezależne, biorąc pod uwagę zdrowie i wiek. Ponadto w artykule pokazano, że samopoczucie tych, którzy przeszli na emeryturę pomiędzy pierwszą a drugą falą, przyjmuje rozkład łańcuchu Markowa. Oznacza to, że subiektywne samopoczucie mierzone w trzeciej fali jest niezależne od tego z pierwszej fali, biorąc pod uwagę falę drugą. Wyniki zaprezentowane tutaj potwierdzają, że emerytura wiąże się z czasowym spadkiem poziomu samopoczucia.

Słowa kluczowe: emerytura, marginalny model log-liniowy, odczuwane samopoczucie 